\title{
Genetic Relatedness of Ornamental Ficus Species and Cultivars Analyzed by Amplified Fragment Length Polymorphism Markers
}

\author{
Jinggui Fang ${ }^{1}$ \\ Department of Botany and Plant Sciences, University of California-Riverside, Riverside, CA 92521 \\ Jianjun Chen ${ }^{2,5}$ and Richard J. Henny ${ }^{3}$ \\ University of Florida, IFAS, Environmental Horticulture Department and Mid-Florida Research and \\ Education Center, 2725 Binion Road, Apopka, FL 32703 \\ Chih-Cheng T. Chao ${ }^{4}$ \\ Department of Botany and Plant Sciences, University of California-Riverside, Riverside, CA 92521
}

\begin{abstract}
AdDitional Index words. AFLP analysis, fig, Moraceae, tropical ornamental foliage plants
Abstract. Ornamental Ficus L. is a group of lactiferous trees, shrubs, and woody root-climbing vines that are cultivated either as landscape plants in the tropics and subtropics or as foliage plants used worldwide for interiorscaping. With the recent rapid expansion of the ornamental plant industry, more new Ficus species and cultivars have been introduced. However, no study has thus far addressed the genetic relationships of cultivated ornamental Ficus. Using amplified fragment length polymorphism (AFLP) markers with near-infrared fluorescencelabeled primers, this study analyzed the genetic relatedness of 56 commercial cultivars across 12 species. Forty-eight $E c o R I+2 / M s e I+3$ primer set combinations were initially screened, from which six primer sets were selected and used in this investigation. Most cultivars were differentiated by their AFLP fingerprints, and their relationships were determined using the unweighted pair-group method of arithmetic average cluster analysis. The 56 cultivars were divided into 12 clusters that correspond to 12 species, indicating that no interspecific hybrids of ornamental Ficus are in commercial production. The 12 species are genetically diverse, with Jaccard's similarity coefficients ranging from 0.21 to 0.43. However, cultivars within three species-Ficus benjamina L., Ficus elastica Roxb. Ex Hornem., and Ficus pumila L. - are genetically close. Twenty-seven of the 29 cultivars of $F$. benjamina and five cultivars of $F$. pumila had Jaccard's similarity coefficients of 0.98 or higher respectively. Nine cultivars of $F$. elastica shared Jaccard's coefficients higher than 0.96 . These results indicate potential genetic vulnerability of these cultivars within the three species. Because there are increasing reports of invasive pests in the ornamental plant industry, strategies for conserving genetic resources and broadening genetic diversity of cultivated Ficus are discussed.
\end{abstract}

The genus Ficus, commonly referred to as fig, belongs to the family Moraceae and encompasses about 800 species (Corner, 1965; Liberty Hyde Bailey Hortorum, 1976). Figs are woody trees, shrubs, climbers, or hemiepiphytic stranglers native to the tropics of Asia, Africa, Australia, and Central America to South America (Condit, 1969; Huxley, 1994). Ficus species are monoecious or functionally dioecious according to their representation of the unisexual florets within the syconium (Cook and Lopez-Vaamonde, 2001; Weiblen, 2000). Most Ficus species are diploid with the basic chromosome number $x=13$ (Condit, 1969). Among cultivated species, Ficus

Received for publication 31 Jan. 2007. Accepted for publication 5 July 2007. We thank Agri-Starts II, Inc., Bruce Jensen Nurseries/Florida LLP, Deroose Plants, Inc., Hermann Engelmann Greenhouses, Inc., Jacbson's Plants, Inc., O. F. Nelson and Sons Nursery, and Penang Nursery, Inc., Apopka, FL; Miami Agra-Starts, Inc., Homestead, FL; and Plug Source, LLC., Mt. Dora, FL, for providing Ficus cultivars used in this study. We also thank Russell D. Caldwell for collecting the plant samples.

${ }^{1}$ Former Postdoctoral Associate. Current address: Department of Biochemistry and Cell Biology, Rice University, 6100 Main Street, Houston, TX 77005.

${ }^{2}$ Associate Professor.

${ }^{3}$ Professor.

${ }^{4}$ Former Associate Cooperative Extension Specialist and Associate Horticulturist. Current address: Thermal Plaza Nursery LLC, 68035-P Hwy 86/Harrison Street, Thermal, CA 92274.

${ }^{5}$ Corresponding author. E-mail: jjchen@ifas.ufl.edu. carica $\mathrm{L}$. has been grown for its edible fruit. Other species, such as $F$. benjamina, F. elastica, Ficus lyrata Warb., and F. pumila are grown for their ornamental value either as landscape plants in the tropics and subtropics (Dehgan, 1998) or foliage plants used for interiorscaping (Chen et al., 2005). In addition to a wide variety of growth habits, leaf shapes among species vary from round to linear-lanceolate, and sizes range from $2 \mathrm{~cm}$ in diameter to $40 \mathrm{~cm}$ long and $20 \mathrm{~cm}$ wide. A large number of cultivars are also valued for their distinct leaf variegation patterns. Although complete data regarding the economic value of ornamental Ficus is not available, the wholesale value of Ficus as foliage plants alone was \$24 million in the United States (U.S. Department of Agriculture, 1999). Florida is the leading state in the United States in the production of ornamental Ficus plants, followed by California, Hawaii, and Texas.

With the increasing growth of the ornamental industry, more new plants and cultivars have been introduced (Chen et al., 2002). New Ficus species introduced during the past 10 years include $F$. altissima Blume, $F$. binnendykii (Miq.) Miq., $F$. deltoidea Jack, $F$. microcarpa Blume, $F$. neriifolia Reinw. ex Steud., F. sagittata Vahl., and F. subulata Blume. The number of Ficus cultivars used as foliage plants increased from 14 in 1975 to 42 in 2004 (Florida Nurserymen and Growers Association, 1975, 2004), of which more than 25 
were patented in the United States (Henny and Chen, 2003). Most of the patented new cultivars were developed from either sports or somaclonal variants. Meanwhile, cultivar discontinuation is also occurring at a fast pace. For example, when the cultivar list in the FNGA Locator 2003-2004 (Florida Nurserymen and Growers Association, 2004) was compared with that in the FNGA Locator 1993-1994 (Florida Nurserymen and Growers Association, 1994), it was found that six cultivars of $F$. benjamina, one cultivar of $F$. elastica, and two cultivars of $F$. lyrata were no longer listed in production. Such a rapid discontinuation of cultivars in production has resulted in germplasm erosion. However, there has been no study thus far aimed at the identification and conservation of cultivated ornamental Ficus.

An important step toward conserving and using germplasm is to characterize available cultivars morphologically and genetically. As ornamental figs are propagated vegetatively, genetic characterization based on molecular markers could be the best alternative. Among the molecular marker techniques, amplified fragment length polymorphism (AFLP) is a novel polymerase chain reaction (PC)R-based assay for DNA fingerprinting and polymorphism detection (Vos et al., 1995). The advantages of this technique include reproducibility, high levels of polymorphism detection, genomewide distribution of markers, and no requirement for prior knowledge of the genome being studied (Mueller and Wolfenbarger, 1999; Prabhu and Gresshof, 1994). The AFLP technique has been widely used for studying genetic relationships among cultivars of different species or genera, including ornamentals, such as Aglaonema Schott (Chen et al., 2004b), Dieffenbachia Schott (Chen et al., 2004a), Euphorbia pulcherrima Willd. Ex Klotzch (Parks and Moyer, 2004), Hemerocallis L. (Tomkins et al., 2001), and Rosa L. (Vosman et al., 2004). The objective of this study was to determine the genetic relatedness of currently cultivated ornamental Ficus species and cultivars using AFLP markers.

\section{Materials and Methods}

Plant materials. Fifty-six cultivars of Ficus across 12 species were collected from either the research greenhouses at the University of Florida's Mid-Florida Research and Education Center in Apopka, or ornamental foliage plant nurseries in central or southern Florida. The source, origin, and key morphological characteristics of the cultivars are briefly described in Table 1.

FLUORESCENT AMPLIFIED FRAGMENT LENGTH POLYMORPHISM ANALYSIS. Amplified fragment length polymorphism analysis was conducted using the GIBCO BRL AFLP System II (Life Technologies, Grand Island, NY) and was based on the work by Chen et al. (2004b). Briefly, total DNA was extracted from young leaves of the collected Ficus 56 cultivars using the DNeasy system (Qiagen, Valencia, CA). After quantification, $125 \mathrm{ng}$ total DNA from all samples was digested with a $1-\mu \mathrm{L}$ mixture of EcoRI/MseI $(1.25 \mathrm{U} / \mu \mathrm{L})$ at $37^{\circ} \mathrm{C}$ overnight, and ligated to EcoRI/MseI adapters with $1.5 \mu \mathrm{L}(1 \mathrm{U} / \mu \mathrm{L}) \mathrm{T} 4$ DNA ligase at $25^{\circ} \mathrm{C}$ for at least $6 \mathrm{~h}$. The adaptor-ligated DNA was amplified using a mixture of $2.5 \mu \mathrm{L}$ DNA from the ligation reaction, $20 \mu \mathrm{L}$ Pre-amp mix II, $2.5 \mu \mathrm{L} 10 \times$ PCR buffer, and $0.2 \mu \mathrm{L}$ Taq DNA polymerase $(5 \mathrm{U} / \mu \mathrm{L})$. The preamplification reactions were performed on an MJR Cycle LR (MJ Research, Watertown, MA) using the following cycling parameters:
30 cycles at $94{ }^{\circ} \mathrm{C}$ for $15 \mathrm{~s}, 56{ }^{\circ} \mathrm{C}$ for $30 \mathrm{~s}+1 \mathrm{~s} /$ cycle, and $72{ }^{\circ} \mathrm{C}$ for $1 \mathrm{~min}+1 \mathrm{~s} /$ cycle, then 1 cycle at $72{ }^{\circ} \mathrm{C}$ for $3 \mathrm{~min}$.

The preamplified PCR product was quantified using the Hoefer DyNA Quant 200 Fluorometer (Pharmacia Biotech, Piscataway, NJ) as described by Teare et al. (1997), and the amount of template for subsequent PCR was diluted to $125 \mu \mathrm{g} \cdot \mu \mathrm{L}^{-1}$. Selective amplification was performed in a reaction mix composed of $2 \mu \mathrm{L}$ DNA from preamp, $2 \mu \mathrm{L}$ MseI primer $(8.3 \mu \mathrm{M}), 0.5 \mu \mathrm{L}$ IRD700-labeled EcoRI primer $(1 \mu \mathrm{M})$, $0.5 \mu \mathrm{L}$ IRD800-labeled EcoRI primer $(1 \mu \mathrm{M}), 1 \mu \mathrm{L} 10 \times$ PCR buffer, $4 \mu \mathrm{L} \mathrm{H}_{2} \mathrm{O}$, and $0.16 \mu \mathrm{L}$ Taq DNA polymerase (5 units/ $\mu \mathrm{L})$ using a touchdown program as follows: 13 cycles at $94{ }^{\circ} \mathrm{C}$ for $15 \mathrm{~s}, 65^{\circ} \mathrm{C}$ for $30 \mathrm{~s}\left(0.7^{\circ} \mathrm{C} /\right.$ cycle $)$, and $72^{\circ} \mathrm{C}$ for $1 \mathrm{~min}$, then 30 cycles at $94{ }^{\circ} \mathrm{C}$ for $15 \mathrm{~s}, 56^{\circ} \mathrm{C}$ for $30 \mathrm{~s}+1 \mathrm{~s} /$ cycle, $72{ }^{\circ} \mathrm{C}$ for $1 \mathrm{~min}+1 \mathrm{~s} / \mathrm{cycle}$, then $72^{\circ} \mathrm{C}$ for $3 \mathrm{~min}$. Both pre- and selectiveamplification conditions were modified according to Myburg et al. (2001). The products from the selective amplification were electrophoresed on $8 \%$ denaturing polyacrylamide Long Range Gel (BMA, Rockland, ME; $25 \mathrm{~cm} \times 0.25 \mathrm{~mm}$ ) in $0.8 \times$ TBE (Tris-Borate-EDTA) buffer using a LI-COR automated sequencer 4000-L (LI-COR, Lincoln, NE). The gel was prerun for 10 to $20 \mathrm{~min}$ at $1500 \mathrm{~V}, 40 \mathrm{~mA}$, and $40 \mathrm{~W}$ until the gel temperature reached $50{ }^{\circ} \mathrm{C}$. The samples were denatured at $95^{\circ} \mathrm{C}$ for $3 \mathrm{~min}$ and immediately placed on ice. Electrophoreses were performed at $1500 \mathrm{~V}, 50{ }^{\circ} \mathrm{C}$ for $3.5 \mathrm{~h}$ after $1.15-\mu \mathrm{L}$ samples and $1 \mu \mathrm{L}$ of a mixture of IRD700 and IRD800 size markers were loaded.

A total of 48 AFLP primers were initially screened, from which six primer sets (IRD700 $\mathrm{E}+\mathrm{AT} / \mathrm{M}+\mathrm{CAG}$, IRD800 $\mathrm{E}+\mathrm{CG} / \mathrm{M}+\mathrm{CTT}$, IRD700 $\mathrm{E}+\mathrm{CT} / \mathrm{M}+\mathrm{CTA}$, IRD800 $\mathrm{E}+\mathrm{GA} /$ $\mathrm{M}+\mathrm{CTT}$, IRD700 $\mathrm{E}+\mathrm{TG} / \mathrm{M}+\mathrm{CAG}$, and IRD700 $\mathrm{E}+\mathrm{GT} /$ $\mathrm{M}+\mathrm{CTA})$ that showed clear scorable and polymorphic fragments (Table 2) were selected. To confirm their reliability, the six primer sets were used to perform reactions again before being used for fluorescent AFLP reactions with the samples of the 56 Ficus cultivars listed in Table 1.

Data AnAlysis. For the genetic similarity analysis, AFLP fragments were visually scored as present (1) or absent (0) to create the binary data set. The data were entered into a binary data matrix as discrete variables. Jaccard's similarity coefficients (Sneath and Sokal, 1973) were calculated for all pairwise comparisons among the 56 Ficus cultivars as follows: Jaccard $=$ $\mathrm{N}_{\mathrm{AB}} /\left(\mathrm{N}_{\mathrm{AB}}+\mathrm{N}_{\mathrm{A}}+\mathrm{N}_{\mathrm{B}}\right)$, where $\mathrm{N}_{\mathrm{AB}}$ is the number of bands shared by two cultivars ( $\mathrm{A}$ and $\mathrm{B}$ ), $\mathrm{N}_{\mathrm{A}}$ represents amplified fragments in cultivar $\mathrm{A}$ only, and $\mathrm{N}_{\mathrm{B}}$ represents fragments in cultivar B only. A dendrogram was generated using NTSYS version 2.1 (Exeter Software, Setauket, NY) (Rohlf, 2000) based on the unweighted pair-group method of arithmetic average cluster analysis (UPGMA).

\section{Results and Discussion}

AMPLIFIED RESTRICTION LENGTH POLYMORPHISM PROFILES. The six primer sets generated clear AFLP profiles for the 56 Ficus cultivars (data not shown). A total of 1253 scorable AFLP fragments were generated, of which $1235(98.56 \%)$ were polymorphic (Table 2). The fragments ranged from 50 to $650 \mathrm{bp}$, with a majority of the polymorphism being distributed between 150 and $400 \mathrm{bp}$. On average, each primer set produced 208.8 fragments, with 205.8 fragments being polymorphic. Primer set E-GA+M-CTT generated the highest (340) 
Table 1. Names, background, morphology, origin, and source of 56 Ficus cultivars across 12 species analyzed by amplified fragment length polymorphism markers for their genetic relatedness.

\begin{tabular}{|c|c|c|c|c|}
\hline Cultivar & Background & Morphology & Origin & Source \\
\hline Alii & Ficus binnendykii & $\begin{array}{l}\text { Long, saber-shaped } \\
\text { leaves, dark green }\end{array}$ & Southeast Asia & $\mathrm{MREC}^{\mathrm{z}}$ \\
\hline Altissima & F. altissima & $\begin{array}{l}\text { Waxy leaves with } \\
\text { yellowish white variegation }\end{array}$ & Southeast Asia & MREC \\
\hline Amstel King & $\begin{array}{l}\text { Sport of } \\
\text { F. binnendykii Alii }\end{array}$ & $\begin{array}{l}\text { Much larger } \\
\text { leaves than Alii }\end{array}$ & $\begin{array}{l}\text { Aalsmeer, } \\
\text { The Netherlands }\end{array}$ & MREC \\
\hline Arina & F. pumila & $\begin{array}{l}\text { Vine with green, } \\
\text { ovate leaves }\end{array}$ & East Asia & $\begin{array}{l}\text { Hermann Engelmann } \\
\text { Greenhouses, Inc. }{ }^{\mathrm{y}}\end{array}$ \\
\hline Burgundy & F. elastica & $\begin{array}{l}\text { Large, waxy, blackish } \\
\text { purple leaves }\end{array}$ & Unknown & Plug Source ${ }^{\mathrm{x}}$ \\
\hline Cabernet & F. elastica & $\begin{array}{l}\text { Large, waxy, dark } \\
\text { purplish leaves }\end{array}$ & Unknown & MREC \\
\hline Common & F. benjamina & Green leaves & Southeast Asia & MREC \\
\hline Curly & F. pumila & $\begin{array}{l}\text { Vine with green } \\
\text { and white variegation }\end{array}$ & East Asia & $\begin{array}{l}\text { Hermann Engelmann } \\
\text { Greenhouses, Inc. }\end{array}$ \\
\hline Dwarf Nina & $F$. benjamina & $\begin{array}{l}\text { Variegated leaves } \\
\text { with white margins }\end{array}$ & Unknown & $\begin{array}{l}\text { Hermann Engelmann } \\
\text { Greenhouses, Inc. }\end{array}$ \\
\hline Fiddle Leaf & F. lyrata & $\begin{array}{l}\text { Coriaceous leaves } \\
\text { with large size }\end{array}$ & Tropical Africa & Agri-Starts II, Inc. \\
\hline Florida Spire & $F$. benjamina & $\begin{array}{l}\text { Green leaves with } \\
\text { columnar growth style }\end{array}$ & Florida & MREC \\
\hline Fruit Fig & F. carica & $\begin{array}{l}\text { Three- to five-lobed } \\
\text { leaves }\end{array}$ & Turkey & $\begin{array}{l}\text { O.F. Nelson } \\
\text { and Sons Nursery }\end{array}$ \\
\hline Russell & F. microcarpa & $\begin{array}{l}\text { Green leaves with } \\
\text { ginsenglike roots }\end{array}$ & Malay to Borneo & Penang Nursery, Inc. ${ }^{\mathrm{u}}$ \\
\hline Moh & F. microcarpa & $\begin{array}{l}\text { Dense leaves with } \\
\text { ginsenglike roots }\end{array}$ & Florida & MREC \\
\hline Little Denmark & $F$. benjamina & $\begin{array}{l}\text { Small, green } \\
\text { leaves }\end{array}$ & Unknown & $\begin{array}{l}\text { Hermann Engelmann } \\
\text { Greenhouses, Inc. }\end{array}$ \\
\hline Little Fiddle & F. lyrata & $\begin{array}{l}\text { Coriaceous leaves with } \\
\text { small size }\end{array}$ & Unknown & Agri-Starts II, Inc. \\
\hline $\begin{array}{l}\text { Little Gold } \\
\text { Angel }\end{array}$ & F. benjamina & $\begin{array}{l}\text { Small leaves } \\
\text { with variegation }\end{array}$ & Unknown & $\begin{array}{c}\text { Hermann Engelmann } \\
\text { Greenhouses, Inc. }\end{array}$ \\
\hline Little Variegata & F. benjamina & Small variegated leaves & Unknown & MREC \\
\hline Marsha & F. elastica & Waxy dark-green leaves & Unknown & MREC \\
\hline Melany & $\begin{array}{l}\text { Sport of } \\
\text { F. elastica Decora }\end{array}$ & Shiny dark-green leaves & $\begin{array}{l}\text { Gravenzande, } \\
\text { The Netherlands }\end{array}$ & Miami Agra-Starts \\
\hline Midnight-cutting & $\begin{array}{l}\text { Sport of } \\
\quad F . \text { benjamina Exotica }\end{array}$ & $\begin{array}{l}\text { Dark-green leaves with } \\
\text { a compact and } \\
\text { bushy growth habit }\end{array}$ & $\begin{array}{l}\text { Gravenzande, } \\
\text { The Netherlands }\end{array}$ & Miami Agra-Starts \\
\hline Midnight & $\begin{array}{l}\text { Sport of } \\
\text { F. benjamina Exotica }\end{array}$ & $\begin{array}{l}\text { More compact growth } \\
\text { style than the cutting }\end{array}$ & $\begin{array}{l}\text { Gravenzande, } \\
\text { The Netherlands }\end{array}$ & Miami Agra-Starts \\
\hline Midnight Princess & $F$. benjamina & Dark-green leaves & Unknown & Miami Agra-Starts \\
\hline Mini Lucie & $F$. benjamina & Dark-green leaves & Unknown & $\begin{array}{l}\text { Hermann Engelmann } \\
\text { Greenhouses, Inc. }\end{array}$ \\
\hline Mistletoe Fig & $F$. deltoidea & $\begin{array}{l}\text { Small leaves with } \\
\text { bushy growth style }\end{array}$ & Southeast Asia & MREC \\
\hline
\end{tabular}


Table 1. Continued.

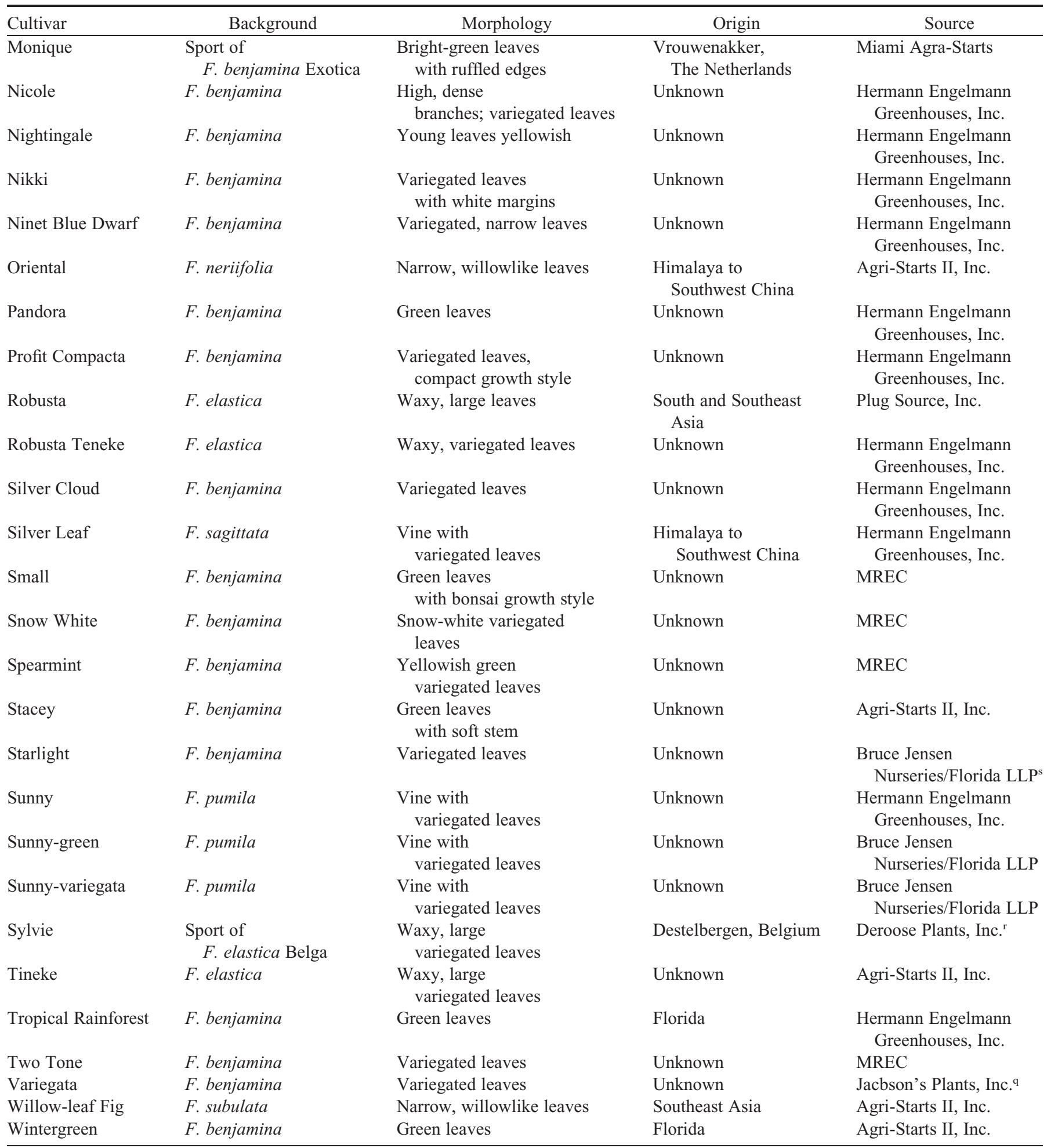

${ }^{\mathrm{z}}$ University of Florida, Mid-Florida Research and Education Center, Apopka, FL.

y Hermann Engelmann Greenhouses, Inc., Apopka, FL.

xPlug Source, LLC., Mt. Dora, FL.

wAgri-Starts II, Inc., Apopka, FL.

${ }^{\mathrm{v}}$ O.F. Nelson and Sons Nursery, Apopka, FL.

uPenang Nursery, Inc., Apopka, FL.

${ }^{\mathrm{t}}$ Miami Agra-Starts, Inc., Homestead, FL.

sBuce Jensen Nurseries/Florida LLP, Apopka, FL.

${ }^{r}$ Deroose Plants, Inc., Apopka, FL.

'Jacbson's Plants, Inc., Apopka, FL. 
Table 2. Amplified fragment length polymorphism primer combinations, primer sequences, total number of fragments generated by each primer set, number of polymorphic fragments detected, and percentages of polymorphic fragments used in this study of Ficus cultivars.

\begin{tabular}{lccc}
\hline Primer pairs & $\begin{array}{c}\text { Total } \\
\text { fragments }(\mathrm{n})\end{array}$ & $\begin{array}{c}\text { Polymorphic } \\
\text { fragments }(\mathrm{n})\end{array}$ & $\begin{array}{c}\text { Proportion of } \\
\text { polymorphic } \\
\text { fragments (\%) }\end{array}$ \\
\hline E-AT+M-CAG & 217 & 212 & 97.70 \\
E-CG+M-CTT & 197 & 196 & 99.49 \\
E-CT+M-CTA & 131 & 127 & 96.95 \\
E-GA+M-CTT & 340 & 337 & 99.12 \\
E-TG+M-CAG & 191 & 186 & 97.38 \\
E-GT+M-CTA & 177 & 177 & 100.00 \\
Total & 1253 & 1235 & \\
Average & 208.83 & 205.83 & 98.56 \\
\hline
\end{tabular}

scorable fragments, while E-GT+M-CTA produced the lowest (177) fragments.

Genetic Relationships among CULTivars. A dendrogram for the 56 Ficus cultivars was constructed based on the UPGMA analysis using Jaccard's similarity coefficients (Fig. 1). The 56 cultivars were divided into 12 clusters. Cluster I contained $F$. altissima only, which is known as council tree, false banyan, or lofty fig. Leaves are thick, ovate to elliptic, and $25 \mathrm{~cm}$ long and $15 \mathrm{~cm}$ wide (Fig. 2A). It grows up to $23 \mathrm{~m}$ in its natural habitat. The yellowish white foliar variegation makes it one of the most attractive figs produced either as a landscape or potted foliage plant.
Cluster II was composed of 29 cultivars, and all belonged to $F$. benjamina, commonly known as weeping fig. Weeping figs are graceful shrubs or trees, and some grow to a height of $30 \mathrm{~m}$ in the tropics. Leaves are entire, glabrous, light to darkgreen or with yellow to white variegation (Fig. 2B). Ficus benjamina is the most popular tree used for interiorscaping (Chen et al., 2002). Cultivars in cluster II are genetically close. Among the 29 cultivars, 27 shared Jaccard's similarity coefficients of 0.98 or higher. Two cultivars, Florida Spire and Tropical Rainforest, shared a Jaccard's similarity coefficient of 0.95 , but the similarity coefficient between these two and the rest was 0.66. All cultivars in this cluster were differentiated based on their Jaccard's similarity coefficients except those in five groups: 'Profit Compact' and 'Silver Cloud' as one group; 'Midnight-cutting', 'Mini Lucie', 'Nikki', and 'Ninet Blue Dwarf' as the second group; 'Little Denmark' and 'Little Gold Angel' as the third; 'Midnight Princess' and 'Midnight' as the fourth; and 'Monique' and 'Nicole' as the fifth group that were indistinguishable. The unsuccessful differentiation of the cultivars within the five groups may be attributed to several factors. One possibility is that cultivars are indeed identical. For example, 'Profit Compact' and 'Silver Cloud' have the same pattern of foliar variegation and growth form; it is likely that they are actually the same cultivar with different names. Another possibility is that some clones are so close genetically that AFLP markers were unable to distinguish them. For example, 'Midnight Princess' was a sport selected from 'Midnight'. 'Midnight', a sport selected from $F$. benjamina 'Exotica', has dark-green leaves and a bushy growth form. It was patented in 1995 with U.S. plant patent no. PP9856

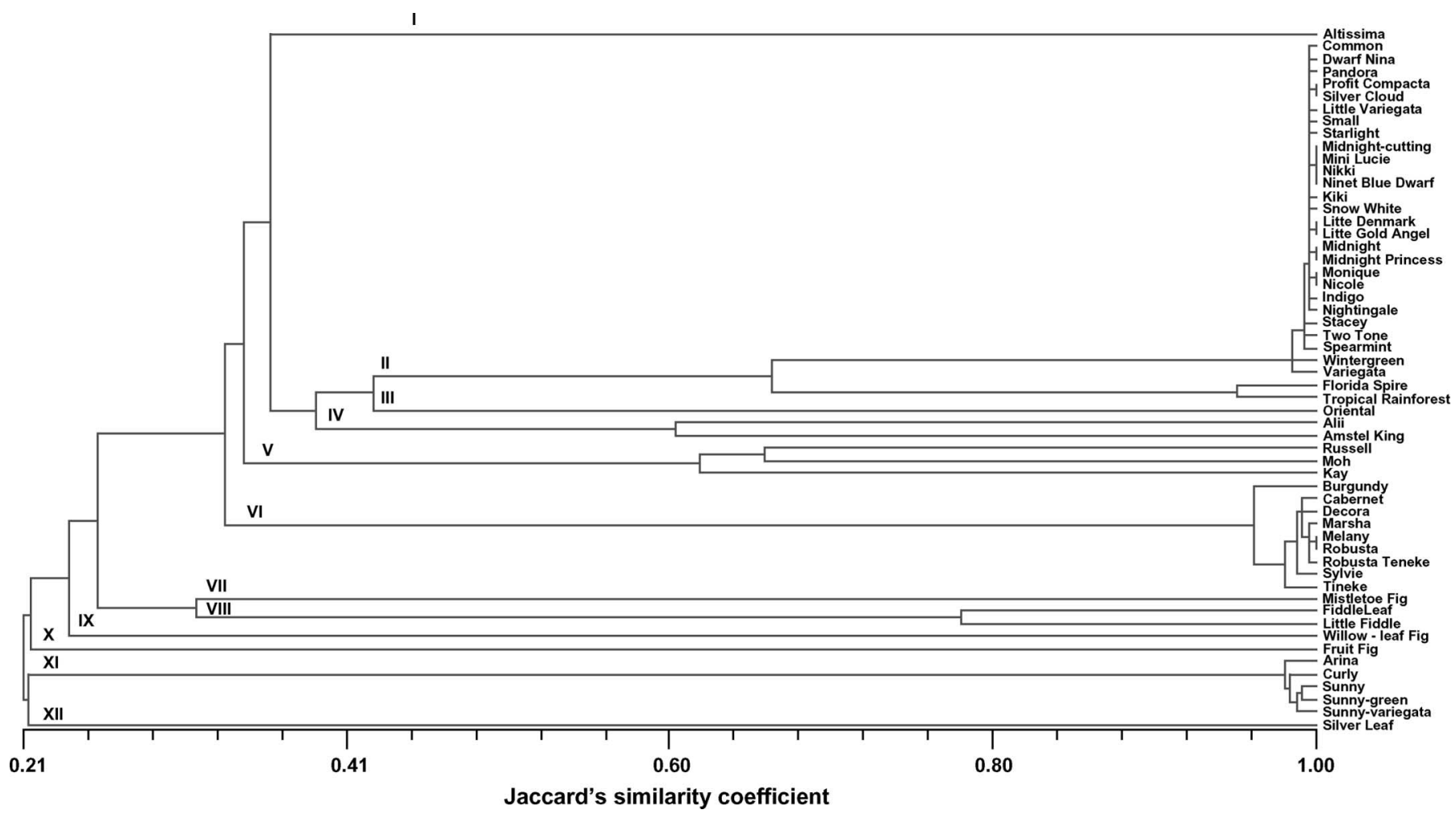

Fig. 1. Dendrogram of 56 Ficus cultivars across 12 species resulting from the unweighted pair-group method of arithmetic average cluster analysis based on Jaccard's similarity coefficients obtained from 1253 AFLP markers. The 56 cultivars were divided into 12 clusters, and each cluster represented a species (I, $F$. altissima; II, F. benjamina; III, F. neriifolia; IV, F. binnendykii; V, F. microcarpa; VI, F. elastica; VII, F. deltoidea; VIII, F. lyrata; IX, F. subulata; X, F. carica; XI, F. pumila; and XII, F. sagittata). 

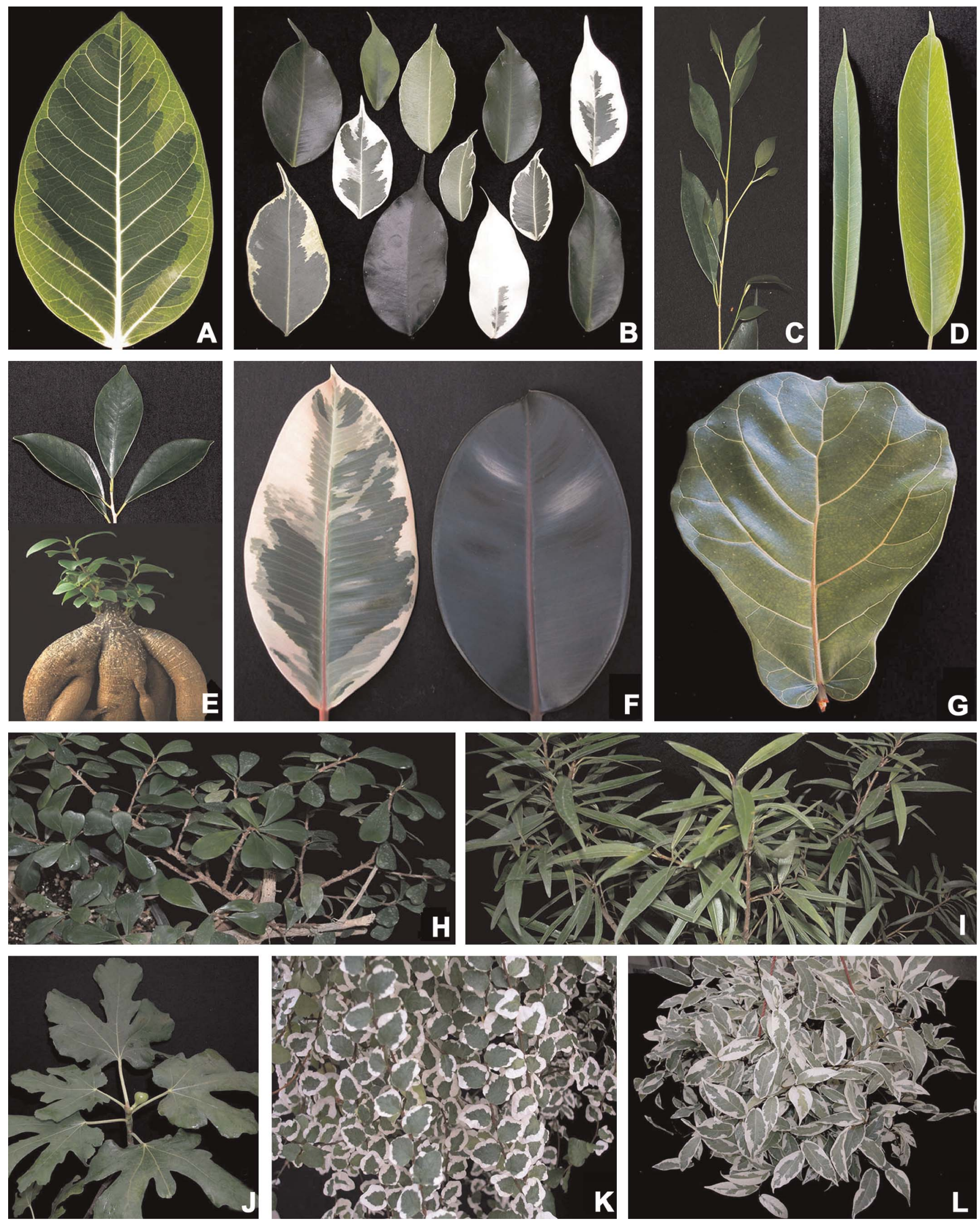

Fig. 2. Ficus species used in this study. (A) A leaf of F. altissima. (B) Leaves of selected $F$. benjamina cultivars. (C) A portion of a small branch of $F$. neriifolia. (D) A leaf of $F$. binnendykii 'Alii' (left) and 'Amstel King' (right). (E) Leaf (top) and ginseng fig (bottom) of $F$. microcarpa. (F) Leaf of $F$. elastica 'Tineke'

(left) and 'Melany' (right). (G) Leaf of $F$. lyrata. (H) Canopy of $F$. deltoidea. (I) Canopy of $F$. subulata. (J) Leaves and small fruit of $F$. carica. (K) Ficus pumlia. (L) Ficus sagittata. 
(van Geest, 1995). 'Midnight Princess' has the same growth style as 'Midnight'; the only difference is that the foliar color of the former appears blue-black. 'Little Denmark' and 'Little Gold Angel' were morphologically similar with the exception that the former has light-green variegation along leaf margins. It is not uncommon that some genetically close clones cannot be distinguished by AFLP analysis. Parks and Moyer (2004) did not differentiate some clones of poinsettia (E. pulcherrima), and Fossati et al. (2005) were unable to distinguish several clones of poplar (Populus L.). On the other hand, the four cultivars in the second group are morphologically different. Although both 'Mini Lucie' and 'Nikki' have compact growth form, the leaf color of 'Nikki' is much lighter and the leaf shape a little narrower than those of 'Mini Lucie'. 'Midnight-cutting' is similar to 'Midnight' as described earlier. 'Ninet Blue Dwarf' is a variegated, small plant. Similarly, two cultivars, Monique and Nicole, also vary morphologically. 'Monique' is another sport selected from $F$. benjamina 'Exotica', with plant patent no. PP8637 (van Diemen, 1992), and it is a large plant with highly glossy, crisp ruffled foliage. 'Nicole' is a small plant with variegated leaves. However, the AFLP analysis was unable to distinguish the four in the second group and the two in the fifth group. It is possible that DNA methylation may be implicated in the cultivar identification. DNA methylation can affect phenotypes by altering gene expression but without changing the nucleotide sequence. As a result, AFLP analysis was unable to detect the variation at the DNA level. Further research using methylation-sensitive amplified polymorphism analysis (Portis et al., 2004) to determine whether methylation occurs among cultivars of these two groups is needed.

There was one cultivar, Oriental, in cluster III, which belongs to $F$. neriifolia. It has dark-gray bark, green to palegreen branchlets, and ovate-lanceolate leaves (Fig. 2C). Cluster IV contained $F$. binnendykii 'Alii' and 'Amstel King'. 'Amstel King' is a sport selected from 'Alii' and was patented in 1993 with patent no. PP8776 (van Diemen, 1993). Both have linearlanceolate leaves, but leaves of 'Amstel King' are larger and broader (Fig. 2D). 'Amstel King' also has newly growing leaves of a pronounced pink to reddish color, and it grows $30 \%$ faster than its parent plant under the same production conditions. Genetically, they differed by a Jaccard's similarity coefficient of 0.61 .

Three cultivars were positioned in cluster $\mathrm{V}$; they are $F$. microcarpa, commonly referred to as indian laurel, malay banyan, or chinese banyan. Leaves are a deep, glossy green; oval-elliptic to diamond shaped, with short, pointed ridged tips (Fig. 2E). This species can grow up to $25 \mathrm{~m}$ in the wild. Recent interest in this species is largely attributed to the fact that its roots can be induced to form structures resembling those of the eastern herb, siberian ginseng Eleutherococcus sessiliflorus (Rupr. \& Maxim.) S.Y. Hu. As a result, cultivars used in the ornamental plant industry are often called ginseng fig. Three common cultivars used in this study are genetically distant because Jaccard's similarity coefficient of 'Kay' with both 'Russell' and 'Moh' was 0.62, and the coefficient between 'Russell' and 'Moh' was 0.66.

Cluster VI contained nine cultivars of $F$. elastica. This species has large (15 to $30 \mathrm{~cm}$ long and 5 to $10 \mathrm{~cm}$ wide), thick, glossy leaves that are either dark green or variegated (Fig. 2F). In its natural habitat, it can reach up to $30 \mathrm{~m}$. Ficus elastica was cultivated in England as early as 1815, with common names of india rubber tree, india rubber fig, or snake tree. Because of its adaptability to indoor low-light environments, no other species of Ficus is as widely propagated and distributed for containerized plant production as F. elastica (Condit, 1969). Currently cultivated $F$. elastica are genetically close, because Jaccard's similarity coefficients among them were 0.96 or higher. Except for 'Melany' and 'Robusta', all cultivars in this cluster are differentiated by AFLP analysis. 'Melany' is a patented cultivar with a patent no. PP9923 selected from a cultivar called Decora in the Netherlands (van Geest, 1996).

'Mistletoe fig' belongs to $F$. deltoidea and was positioned in cluster VII. This is an evergreen shrub or small tree and is usually bushy (Huxley, 1994). Leaves are broadly spoon shaped to obovate, leathery, 4 to $8 \mathrm{~cm}$ long, and bright-green above and rust-red to olive-brown beneath (Fig. $2 \mathrm{H}$ ). The name "mistletoe fig" was based on the observation that this species often grows as an epiphyte on other plants in the wild, and the thick leaves resemble those of some mistletoes (Phoradendron macrophyllum Trel.) (Condit, 1969).

Two cultivars of $F$. lyrata were situated in cluster VIII. Because of its violin-shaped leaves, $F$. lyrata is commonly called the fiddle leaf fig. The large, veiny, emerald-green leaves are as large as $40 \mathrm{~cm}$ long and $20 \mathrm{~cm}$ wide (Fig. 2G). It is native to tropical Africa, with neither buttresses nor aerial roots. Another characteristic of fiddle leaf fig is its chilling tolerance. Reports show that it tolerates a chilling temperature close to freezing (Condit, 1969). Two cultivars, Fiddle Leaf and Little Fiddle, shared a Jaccard's similarity coefficient of 0.78 . Morphologically, 'Fiddle Leaf' is larger in size, but otherwise the two cultivars seem to be identical.

One cultivar, willow-leaf fig or narrow-leaf fig ( $F$. subulata) was positioned in cluster IX. It is an upright tree, $4.5 \mathrm{~m}$ tall, and is branched from near the base. Leaves are linear-lanceolate but shorter than those of $F$. binnendykii 'Alii' or 'Amstel King' (Fig. 2I). The edible fig $F$. carica was located in cluster X. This is one of the oldest fruits known to civilization (certainly to 2700 BCA) (Huxley, 1994). It is a deciduous shrub or tree, up to $9 \mathrm{~m}$ tall. Leaves, in contrast to many other species, are three to five lobed, rough to the touch above, and pubescent beneath (Fig. 2J). Edible fig is not commonly produced for ornamental purposes, but was included in this study to compare its genetic relatedness to the other figs.

Cluster XI contained five cultivars of $F$. pumila. This species is different from all the aforementioned species in two aspects: First, it is a root climber with freely growing fertile shoots, which explains why its common names are creeping fig, climbing fig, or creeping rubber plant; and second, foliage is dimorphic, having juvenile and adult stages. Juvenile leaves are glabrous, entire, ovate to elliptic, green or variegated, $2.5 \mathrm{~cm}$ long or less (Fig. 2K). Plants in the juvenile stage are widely used as hanging baskets. In the tropics, the evergreen vines generally grow on buildings and cling close to walls. The five cultivars used in this study are genetically close, with Jaccard's similarity of coefficients of 0.98 or higher.

'Silver leaf fig' ( F. sagittata) was positioned in cluster XII. This is another climbing fig with dimorphic foliage. Juvenile leaves are large, oblong-lanceolate, 5 to $10 \mathrm{~cm}$ long, and stems are stronger with a diameter of $3 \mathrm{~mm}$. Leaf surfaces are rough, green or variegated (Fig. 2L). The juvenile stage of this plant is used as hanging baskets for interiorscaping in the ornamental industry.

Genetic Relatedness AMONG SPECIES. This study shows that the 12 clusters identified by the UPGMA analysis represent 
12 species (Fig. 1). Such a clear differentiation of individual species is probably attributed to the fact that each fig species is exclusively pollinated by a unique agaonid wasp species (Agaonidae), whose offspring feed only on the tissue of the characteristic fig fruits (Machado et al., 2001; Ramirez, 1974). As a result, interspecific hybridization seldom occurs in nature. In fact, recent mitochondrial DNA studies suggest that the figagaonid interaction may play an important role in fig species diversification (Cook and Lopez-Vaamonde, 2001; Nason et al., 1998). As a consequence, Jaccard's coefficients among the 12 species are rather distant. The closest species to $F$. benjamina is $F$. nerofolia, followed by $F$. binnendykii, $F$. altissima, $F$. microcarpa, and $F$. elastica, with Jaccard's coefficients of $0.43,0.39,0.37,0.35$, and 0.33 respectively. Ficus deltoidea and $F$. lyrata were clustered together; both have violin-shaped leaves. Jaccard's similarity coefficient between the two species is 0.32 . Two creeping-type figs, $F$. pumila and $F$. sagittata, were closely positioned, sharing a similarity coefficient of 0.21 . Morphologically, one would think that $F$. altissima was close to $F$. elastica because both have large, rubberlike leaves; and $F$. binnendykii and F. subulata would be close because both have narrow, willowlike leaves. The AFLP analysis, however, showed they are genetically distant from each other.

Although each species has been clearly differentiated, controversies regarding the names of several species remain. Ficus binnendykii 'Alii' and 'Amstel King' have been called either F. binnendijkii 'Alii' and 'Amstel King' (Florida Nurserymen and Growers Association, 2004) or F. maclellandii 'Alii' and 'Amstel King' (Henley and Poole, 1989). According to Huxley (1994), F. binnendykii should be considered the proper species name. The most confused name is probably the willow-leaf fig, which has been refereed to as $F$. neriifolia, $F$. salicifolia, F. cordata, and F. subulata. Huxley (1994) indicated that willow-leaf fig is $F$. cordata, and $F$. salicifolia should be either $F$. cordata or F. subulata. Ficus neriifolia has botanical standing as a species (Huxley, 1994; Liberty Hyde Bailey Hortorum, 1976), commonly called oriental fig. The small, narrow-leaf species used in this study (Fig. 2I) is $F$. subulata (Huxley, 1994), which is known as bonsai fig in Asia. However, Berg (2004) gave it a new name: F. salicaria C.C. Berg. Further study is required to confirm this name change. Additionally, F. diversifolia, F. repens, and F. retusa have no botanical standing; they are $F$. deltoidea, $F$. pumila, and F. microcarpa respectively (Huxley, 1994).

GENETIC VULNERABILITY AND GERMPLASM CONSERVATION. An important finding of this study is that commercial cultivars within three popular species ( $F$. benjamina, $F$. elastica, and $F$. pumila) are genetically extremely close. Commercial cultivars with limited genetic diversity are often vulnerable to new diseases and pests (National Academy of Science, 1972). A recent outbreak of a thrips (Gynaikothrips uzeli Zimmerman) has caused severe damage to $F$. benjamina in Florida and several other southern states (Held et al., 2005). This thrips is primarily a gall maker (i.e., leaf folder). Gall formation permanently disfigures leaves, resulting in completely unmarketable plants. A preliminary evaluation of the 56 cultivars in a recent study showed that this thrips specifically infested cultivars of $F$. benjamina. Among the 29 cultivars of $F$. benjamina, only 'Florida Spire' and 'Tropical Rainforest' appeared to have fewer folded leaves than the others. 'Florida Spire' and 'Tropical Rainforest' are landrace cultivars with light-green leaves; they have long been cultivated in Florida. Further studies will determine whether the thrips tolerance is related to the genetic distances of these two cultivars from the rest (Fig. 1). The outbreak of this thrips alarmed the ornamental industry by showing how vulnerable genetically similar cultivars could be to new invasive pests.

Strategies for broadening the genetic base of cultivars within a species are needed. Traditional breeding should be used for increasing the genetic diversity of ornamental figs. As a result of the specific pollination requirements of a fig species and its corresponding wasp, hybridization could be difficult. However, hybrids have been developed in F. carica (Doyle et al., 2003; Storey, 1975), including interspecific hybrids developed from $F$. pumila and F. carica (Storey, 1975). Thus, it is not impossible to broaden the genetic base of ornamental figs through traditional breeding. Another solution is to use more landraces. Landraces generally have considerable diversity that allows adaptation to or tolerance of abiotic and biotic stresses. However, landraces are rapidly being lost as growers are provided with new cloned cultivars. In addition to six cultivars of $F$. benjamina, one cultivar of $F$. elastica and two cultivars of $F$. lyrata that have been removed from production in Florida in the last 10 years, 'Florida Spire' and 'Tropical Rainforest', are also no longer grown but are conserved at the University of Florida. 'Florida Spire' and 'Tropical Rainforest' shared a Jaccard's similarity coefficient of 0.95 , but the coefficient of the two with the other $F$. benjamina cultivars was 0.66 , indicating that some landraces are indeed genetically diverse. Thus, it is important that landraces be collected, preserved, and used in production and breeding. Additionally, the identification and use of sports or somaclonal variants could also be an alternative for enhancing genetic diversity. Although three sport cultivars Indigo, Midnight, and Monique isolated from $F$. benjamina 'Exotica' are genetically close, it is possible that sports or somaclonal variants isolated from other $F$. benjamina cultivars may increase diversity genetically. Distant genetic relationships have been documented in other ornamental plants (Chen and Henny, 2006). For example, Jaccard's similarity coefficient between Philodendron 'Baby Hope' and its parent 'Hope' was 0.62 (Devenand et al., 2004). In this study, 'Amstel King' is a sport of 'Alii'; Jaccard's similarity coefficient between the two was 0.61 .

In addition to enhancing the genetic diversity of cultivars within individual species, the ornamental industry also needs to consider using more fig species. Ficus encompasses about 800 species; some other species may have ornamental value but have not been exploited yet. For example, $F$. benghalensis L., with broadly ovate leaves similar to $F$. altissima; $F$. macrophylla Desf. Ex. Pers., with rubber leaves; and $F$. ulmifolia Lam., with dimorphic foliage could be domesticated and used as ornamental plants. As indicated in this study, fig species are genetically diverse, and utilization of more species would reduce the vulnerability of cultivated figs to new pests and diseases.

\section{Literature Cited}

Berg, C.C. 2004. A new species of Ficus (Moraceae) of uncertain provenance. Brittonia 56:54-57.

Chen, J., P.S. Devanand, D.J. Norman, R.J. Henny, and C.T. Chao. 2004a. Analysis of genetic relatedness of Dieffenbachia cultivars using AFLP markers. J. Amer. Soc. Hort. Sci. 129:81-87. 
Chen, J., P.S. Devanand, D.J. Norman, R.J. Henny, and C.T. Chao. 2004b. Genetic relationships of Aglaonema species and cultivars inferred from AFLP markers. Ann. Bot. (Lond.) 93:157-166.

Chen, J. and R.J. Henny. 2006. Somaclonal variation: An important source for cultivar development of floriculture crops, p. 244-253. In: J.A. Teixeira da Silva (ed.). Floriculture, ornamental and plant biotechnology, vol II. Global Science Books, London, UK.

Chen, J., R.J. Henny, and D.B. McConnell. 2002. Development of new foliage plant cultivars, p. 466-472. In: J. Janick and A. Whipkey (eds.). Trends in new crops and new uses. ASHS Press, Alexandra, VA.

Chen, J., D.B. McConnell, D.J. Norman, and R.J. Henny. 2005. The foliage plant industry. Hort. Rev. (Amer. Soc. Hort. Sci.) 31:47-112. Condit, I.J. 1969. Ficus: The exotic species. Division of Agricultural Science, University of California, Riverside, CA.

Cook, J.M. and C. Lopez-Vaamonde. 2001. Fig biology: Turning over new leaves. Trends Ecol. Evol. 16:11-13.

Corner, E.J.H. 1965. Check-list of Ficus in Asia and Australia, with keys to identification. Gardens' Bul. Singapore 21:1-186.

Dehgan, B. 1998. Landscape plants for subtropical climates. University Press of Florida, Gainesville, FL.

Devenand, P.S., J. Chen, R.J. Henny, and C.T. Chao. 2004. Assessment of genetic relationships among Philodendron cultivars using AFLP markers. J. Amer. Soc. Hort. Sci. 129:690-697.

Doyle, J.F., L. Ferguson, and K. Herman. 2003. Fig cultivar development and evaluation. Acta Hort. 605:29-32.

Florida Nurserymen and Growers Association. 1975. Florida foliage buyer's guide. Florida Nurserymen and Growers Assn., Apopka, FL.

Florida Nurserymen and Growers Association. 1994. FNGA locator 1993-1994. Florida Nurserymen and Growers Assn., Orlando, FL.

Florida Nurserymen and Growers Association. 2004. FNGA locator 2003-2004. Florida Nurserymen and Growers Assn., Orlando, FL.

Fossati, T., I. Zapelli, S. Bisoffi, A. Micheletti, L. Vietto, F. Sala, and S. Castiglione. 2005. Genetic relationships and clonal identity in a collection of commercially relevant poplar cultivars assessed by AFLP and SSR. Tree Genet. Genomes 1:11-20.

Held, D.W., D. Boyd, T. Lockley, and G.B. Edwards. 2005. Gynaikothrips uzeli (Thysanoptera: Phlaeothripidae) in the southeastern United States: Distribution and review of biology. Fla. Entomol. 88:538-540.

Henny, R.J. and J. Chen. 2003. Cultivar development of ornamental foliage plants. Plant Breed. Rev. 23:245-290.

Henley, R.W. and R.T. Poole. 1989. Evaluation of selected ornamental figs for interior use. Proc. Fla. State Hort. Soc. 102:119-123.

Huxley, A. 1994. The new royal horticultural society dictionary of gardening. Macmillan, London, UK.

Liberty Hyde Bailey Hortorum. 1976. Hortus third: A concise dictionary of plants cultivated in the United States and Canada. Macmillan, New York.

Machado, C.A., E. Jousselin, F. Kjellberg, S.G. Compton, and E.A. Herre. 2001. Phylogenetic relationships, historical biogeography and character evolution of fig-pollinating wasps. Proc. R. Soc. Lond. B. Biol. Sci. 268:685-694.

Mueller, U.G. and L.L. Wolfenbarger. 1999. AFLP genotyping and fingerprinting. Trends Ecol. Evol. 14:389-394.

Myburg, A.A., D.L. Remington, D.M. O'Malley, R.R. Sederoff, and R.W. Whetten. 2001. High-throughput AFLP analysis using infrared dye-labeled primers and an automated DNA sequencer. Biotechniques 30:348-357.

Nason, J.D., E.A. Herre, and J.L. Hamrick. 1998. The breeding structure of a tropical keystone plant resource. Nature 391: 685-687.
National Academy of Science. 1972. Genetic vulnerability of major crops. National Academy of Science, Washington, DC.

Parks, E.J. and J.W. Moyer. 2004. Evaluation of AFLP in poinsettia: Polymorphism selection, analysis, and cultivar identification. J. Amer. Soc. Hort. Sci. 129:863-869.

Portis, E., A. Acquadro, C. Comino, and S. Lanteri. 2004. Analysis of DNA methylation during germination of pepper (Capsicum annuum L.) seeds using methylation-sensitive amplification polymorphism (MSAP). Plant Sci. 166:169-178.

Prabhu, R.R. and P.M. Gresshof. 1994. Inheritance of polymorphic markers generated by DNA amplification fingerprinting and their use as genetic markers in soybean. Plant Mol. Biol. 26:105-116.

Ramirez, B.W. 1974. Coevolution of Ficus and Agaonidae. Ann. Missouri Bot. Garden 61:770-780.

Rohlf, F.J. 2000. NTSYSpc, numerical taxonomy and multivariate analysis system, version 2.1 user guide. Exeter Software Publ., Setauket, NY.

Sneath, P.H.A. and R.R. Sokal. 1973. Numerical taxonomy: The principles and practice of numerical classification. Freeman, San Francisco.

Storey, W.B. 1975. Figs, p. 568-589. In: J. Janick and J.N. Moore (eds.). Advances in fruit breeding. Purdue University Press, West Lafayette, IN.

Teare, J.M., R. Islam, R. Flanagan, S. Gallagher, M.G. Davies, and C. Grabau. 1997. Measurement of nucleic acid concentrations using the DyNA Quant and the GeneQuant. Biotechniques 22:1170-1174.

Tomkins, J.P., T.C. Wood, L.S. Barnes, A. Westman, and R.A. Wing. 2001. Evaluation of genetic variation in the daylily (Hemerocallis spp.) using AFLP markers. Theor. Appl. Genet. 102:489-496.

U.S. Department of Agriculture. 1999. 1998 census of horticultural specialties. U.S. Department of Agriculture, Washington, DC.

van Diemen, H.T. 1992. United States patent PP8637. Ficus benjamina plant named 'Monique'. 7 July 2007. <http://patft.uspto.gov/netacgi/ nph-Parser?Sect $1=$ PTO $1 \&$ Sect $2=$ HITOFF $\& d=$ PALL $\& p=1 \& u=$ $\% 2$ Fnetahtm $\% 2$ FPTO $\% 2$ Fsrchnum.htm \& $\mathrm{r}=1 \& \mathrm{f}=\mathrm{G} \& \mathrm{l}=50 \& \mathrm{~s} 1=$ PP08637.PN.\&OS=PN/PP08637\&RS=PN/PP08637>.

van Diemen, H.T. 1993. United States patent PP8776. Ficus maclellandii plant named Ficus 'Amstel King'. 7 July 2007. < http://patft. uspto.gov/netacgi/nph-Parser?Sect $1=$ PTO $1 \&$ Sect $2=$ HITOFF $\& d=$ PALL $\& \mathrm{p}=1 \& \mathrm{u}=\% 2 \mathrm{Fnetahtml} \% 2 \mathrm{FPTO} \% 2 \mathrm{Fsrchnum} . \mathrm{htm} \& \mathrm{r}=1 \& \mathrm{f}=$ $\mathrm{G} \& \mathrm{l}=50 \& \mathrm{~s} 1=\mathrm{PP} 08776 . \mathrm{PN} . \& \mathrm{OS}=\mathrm{PN} / \mathrm{PP} 08776 \& \mathrm{RS}=\mathrm{PN} / \mathrm{PP} 08776>$. van Geest, J. 1995. United States patent PP9856. Ficus variety named 'Midnight'. 7 July 2007. <http://patft.uspto.gov/netacgi/nph-Parser? Sect $1=$ PTO $2 \&$ Sect $2=$ HITOFF $\& p=1 \& u=\% 2$ Fnetahtm $1 \% 2$ FPTO $\%$ 2Fsearch-bool.html $\& \mathrm{r}=2 \& \mathrm{f}=\mathrm{G} \& \mathrm{l}=50 \& \mathrm{co} 1=\mathrm{AND} \& \mathrm{~d}=\mathrm{PTXT} \& \mathrm{~s} 1=$ $\% 22$ ficus + Midnight $\% 22 \& \mathrm{OS}=\% 22$ ficus + Midnight $\% 22 \& \mathrm{RS}=$ $\% 22$ ficus+Midnight $\% 22>$.

van Geest, J. 1996. United States patent PP9923. Ficus variety plant named 'Melany'. 7 July 2007. <http://patft.uspto.gov/netacgi/ nph-Parser?Sect $1=$ PTO $1 \&$ Sect $2=$ HITOFF $\& d=$ PALL $\& p=1 \& u=$ $\% 2$ Fnetahtml $\% 2$ FPTO $\% 2$ Fsrchnum.htm \& $\mathrm{r}=1 \& \mathrm{f}=\mathrm{G} \& 1=50 \& \mathrm{~s} 1=$ PP09923.PN.\&OS=PN/PP09923\&RS=PN/PP09923>.

Vos, P.R., M. Hogers, M. Bleeker, T. van de Lee Reijans, M. Hornes, A. Frijters, J. Pot, J. Peleman, M. Kuiper, and M. Zabeau. 1995. AFLP: A new technique for DNA fingerprinting. Nucl. Acids Res. 23:4407-4414.

Vosman, B., D. Visser, J.R. van der Voort, M.J.M. Smulders, and F. van Eeuwijk. 2004. The establishment of 'essential derivation' among rose varieties, using AFLP. Theor. Appl. Genet. 109:1718-1725.

Weiblen, G.D. 2000. Phylogenetic relationships of functionally dioecious Ficus (Moraceae) based on ribosomal DNA sequences and morphology. Amer. J. Bot. 87:1342-1357. 